\title{
Surviving the Crash: Canadian Universities in the Era of Disillusionment*
}

\author{
DESMOND MORTON**
}

Gloom is very much in fashion in the Western world. Economists predict that the current recession will develop into a catastrophic world depression. Ecologists anticipate mass starvation. Climatologists warn of an imminent return of the Great Ice Age. Armed with batteries of computer projections, the experts from the Club of Rome pester businessmen and bureaucrats while Paul Ehrlich and Robert Heilbroner prod the anxieties of thoughtful liberals and social democrats.

It is probably no coincidence that so many of these despairing trend-setters live in universities. Whether or not a state of no-growth will or should become normal for the rest of technologically advanced society, it has already reached the academic world in Canada, the United States and much of western Europe.

In retrospect, it is apparent that the academic profession is at the end of an exhilarating fifteen-year power trip. The landing was rough. The survivors are shaken and suitably nervious about their future. To be fair, the professors were not solely responsible for the trip. The journey was directed and financed by governments with the enthusiastic support of most editorial opinion. However, academics filled the seats, enjoyed the view and, with a few valiant exceptions, offered no protests against the journey and its consequences. Instead, they pretended that they were participants in a modern equivalent of a Greek academy, responsible only to themselves for their five-figure salaries, their travel grants and their multi-million dollar research equipment.

If brilliance has any advantage over more pedestrian qualities of mind, it is in the grandeur of its delusions. Academics have pretended that they were climbing Parnassus when, in fact, their institutions were being used as artifacts to glorify the creativity of politicians and to satisfy the transient expectations of taxpayers. In Ontario, the equivalent of the enormous sum created by funding the Canada Pension Plan has been spent to expand the facilities of the province's university and community college system. While cornerstones were laid and monumental buildings were erected, the unglamorous early years of public education were virtually ignored and mentally ill children were abandoned in "hospitals" at Orillia and Smith's Falls.

If there was a single supervening rationale for the impressive expansion of post-secondary

\footnotetext{
*Based on a paper given at Memorial University, Newfoundland, as part of that university's 25th anniversary celebrations.
} 
education in Canada, it was the widespread assertion that universities and colleges would furnish much of the motive power for economic growth. The claim was regularly promoted by such influential (although flexible) oracles as John Kenneth Galbraith, but perhaps its more important Canadian formulation could be found in the 1965 report of the Economic Council of Canada. Under the shrewd chairmanship of Dr. John Deutsch, a future principal of Queen's University, the Council insisted that educational investment paid off at rates between fifteen and twenty per cent per year - a usurious return in those pre-inflationary times. Unfortunately, there seems to be a flaw in the argument. After a decade of unprecedented educational investment, the Canadian economy appears to be at a dead stop.

If growth seemed a goal too servile to corporate capitalism, it was easily supplanted, particularly in the United States, by the myth that universities were uniquely fitted to dissolve the injustices of a racist, sexist and class-ridden society. In Canada, by hiring sufficient local talent, they might also eliminate our alleged colonial mentality. Such arguments appealed to the new self-importance of universities and their denizens. If university credentials were indeed a passport to comfortable living and personal fulfilment, justice demanded that they be made equally available to all - perhaps even regardless of demonstrated ability. If universities had been a narrow ladder to a privileged elite, the liberal answer was to put up more ladders. In most parts of Canada, governments encouraged existing universities to expand and often opened new campuses when progress proved too slow to satisfy an impatient electorate. So long as faculty incomes and promotion prospects shared in the general inflation there was little audible protest. The chief burden of teaching the flood of ill-equipped newcomers fell to junior faculty and graduate assistants while senior professors could usually reserve their energies for research, post-graduate students and the rewarding prospects of lateral transfer. The fact that economic inequality is confirmed, if anywhere, at the outset of the educational process was largely ignored by academics, legislators and editorial commentators.

Conservatives and radicals within the university could each burnish their respective myth but they were unanimous about the most self-serving illusion of all. With rare unanimity, university presidents and student revolutionaries agreed that academic institutions were tremendously important. If universities were so central to the economic system, if they possessed such incredible potential for transforming an evil and malfunctioning society, the struggle of the late 1960's for power on university boards, councils and senates and within departments was, perhaps, a real, not a sham, battle.

You cannot swindle an honest man. The mythology which promoted the university and college explosion of the past fifteen years usually rested on unstated but unmistakable material interests. The faculty could abandon the old vow of poverty and self-effacement - once the real underpinning of their academic freedom - and enjoy unprecedented status and income. The students found gratification in imitating and surpassing the self-importance of their teachers. Radicals discovered that a university campus is probably the safest place in the world to play at revolution. The middle classes, who almost invariably manage to find some comfort in this world, soon discovered that lower costs and increased opportunities for higher education were to their substantial advantage. The stockbroker's thickwitted offspring could now meet the reduced admission requirements; the fish packer's clever daughter might never have an opportunity to graduate from high school. Meanwhile, as Ontario's Committee on Post-Secondary Education rudely pointed out, much of the cost of higher education was borne by those who were unlikely ever to profit from it. 
Of course, as any experienced swindler can testify, a confidence trick has a limited lifespan. The growth promoters and their accomplices have vanished or changed their colours, leaving over-expanded colleges and universities vulnerable to the recurrent fashion of antiintellectualism. It should be dismaying to discover that, after a generation in which access to education has expanded almost beyond belief, the two most conspicuous fads among the young are irrational spiritualism and utopian primitivism. At a time when the doomsday theorists are making our flesh creep with warnings of resource depletion, the only unlimited resource is presumably human intelligence. These days, we are regularly warned to regard it as a menace. Perhaps that is fair retribution for institutions which, themselves, endorsed the highly irrational assumption that money, manpower, bricks and mortar were sufficient prerequisites for solving the problems of society.

Unfortunately, while universities were by no means the sole creators of this illusion, their co-conspirators - notably governments - will not stick around to share the rap. Having justified the recent academic power trip by promises they could not fulfil, universities and their faculty now face the fate of the medicine man who did not skip town in time. If universities have such a monopoly of wisdom, some will now ask, why have they no rational or acceptable prescription for our developing economic mess? If universities foster culture and civilization, why have they been centres for so much that is uncivil and destructive? If universities profess to guide governments and business in managing their affairs, why is their own management frequently so time-consuming and inefficient?

Such questions and criticisms are no longer restricted to dyspeptic editors or to knownothing backbenchers, preaching the annual sermon to the folks in Buncombe. Across Canada, provincial governments are looking for ways to limit public spending on an unpopular cause. In Manitoba, Premier Ed Schreyer warned protesting university students that he would prefer to spend extra tax dollars on installing municipal water systems than on granting them free tuition. The Ontario government's decision to cover only half the universities' loss from inflation in their funding formula for 1975-6 became one of the first recent acts of the Davis regime, wise or foolish, to provoke no public outcry. It will almost certainly be followed, once the era of minority rule is over, by the major increase in student fees urged by the Wright Commission. At a time when a university degree is already a barely marketable commodity, increasing its cost should have a devastating impact on enrolments (and on university and college budgets).

Since virtually all major Canadian universities now depend heavily on tax support, tightening purse strings promise a new era of turmoil on Canadian campuses. Still traumatised by almost a decade of struggle with student militants, university administrators now face the wrath of faculty and staff. Some institutions are contemplating the dismissal of tenured professors or the imposition of drastic reductions in their standard of living. Elsewhere, a new academic underclass - unemployed graduate students - competes for ill-paid temporary appointments, always aware that they are an expendable buffer against worse times to come.

In the circumstances, unionization becomes increasingly attractive to university teachers and support staff alike. The thought is no longer unthinkable. Five years ago, who could have predicted the militancy of school teachers or civil servants? Of course, bargaining effectiveness usually depends on a level of public support or public vulnerability which professors should be cautious about testing. They are not primary school teachers, running an essential day-care service, or snowplow operators, withdrawing their services before a 
mid-winter blizzard. Faculty at the University of Manitoba or Carleton University may be disillusioned by the public's tolerance of the loss of their services.

While some argue that faculty and staff unionization will enhance the authority of university boards of governors, it seems more likely that the frail autonomy of governors or trustees would collapse before the onslaught of major financial demands. In 1974, negotiators for Ontario's hospital workers complained that they were bargaining with a shadow: settlement demanded the direct intervention of the provincial treasury, the sole significant source of funds for hospital operations. The price for direct confrontation between professors and their paymasters would be more direct imposition of government priorities - elegantly expressed by an Ontario cabinet minister in recent years as "more scholar for the dollar".

Whether or not unionization could save the academic profession from returning to the meagre salaries and modest status of a generation ago, it offers few other comforting features. The institution of academic tenure is already marked as a victim to the suspicions of students and politicians and to the wrath of younger teachers, now permanently excluded from the guild; but its trade union alternative, job security, would have no less stifling consequences for university staffing. Unionization, with its arbitrary definition of management-employee relations, would also tend to eliminate those features of the university which make it function, albeit imperfectly, as a form of industrial democracy.

In summary, the gloom around most Canadian universities is not only justified but likely to endure. It threatens internal conflict so bitter as to make the student friction of the Sixties as quaint a memory as the panty raids of the Fifties. It might also produce a better kind of university. Hard times are not necessarily ennobling but they are often the only times when hard priorities are chosen. Now that the university power trip is definitely over, the survivors must assess their resources, divide up their duties and get set for a long, hard struggle.

Often overlooked in the catalogue of woes and failings afflicting Canadian universities are some impressive accomplishments. All growth is exhausting and the incredible expansion in students, facilities and staff during the past fifteen years brought invisible as well as visible strains. In spite of them, Canadian universities and colleges also fostered an outpouring of creativity and analysis in both national and regional cultures which have already established the past decade as a critical epoch in our history. The academic community played the leading role, for example, in documenting the consequences of environmental damage and in turning that raw data into public awareness. Would anyone dare to claim that environmental research would have been so significant or so publicised if corporations and governments had enjoyed a monopoly of scientific research or if scientists had been dependent on their private resources?

Examples of achievement during the era of university expansion will multiply with added historical perspective. One which might be forgotten was the incidental contribution of an exploding college and university system in soaking up surplus people. As Walter Pitman, the new president of Ryerson Polytechnical Institute, has pointed out, if Ontario's enrolments in post-secondary education had remained at their 1960 level, Canada's richest province would have experienced unemployment rates of 1930's dimensions. Men and women who were busy venting the frustrations of postponed adulthood on academic administrators might have been pouring their rage on politicians and the economic system 
- with rather more volatile consequences.

In general, Canada's universities should face a difficult future without a debilitating sense of guilt. If some leading scholars gave bad advice, some politicians were foolish enough to take it, and to give some remarkably silly orders in return. Both sides should learn a becoming modesty from the experience.

Of all the illusions of the power trip era, the myth of the Greek academy has probably proved the most durable - if only because it is also comfortable for the faculty. Unhappily, academic freedom has sometimes been confused with a claim to substantial public resources. Not every university can afford a cyclotron or a papyrological collection. Every university must have the strength to protect its scholars, senior and junior, from denunciation for subversion, racism or whatever the fashion in know-nothingism dictates. Scholars who find it intolerable to answer to the community for the validity, if not for the consequences, of their work deserve the freedom and the encouragement to create their own equivalent of the Greek academy as, in a sense, Sir Max Beloff and his associates have recently attempted in Great Britain.

Public universities, like other public institutions, must expect to serve demonstrable public needs but they must have the right to argue - fiercely, if need be - about how best those needs should be met. Universities, for example, have every right to question the ability and preparation of the students who flow into them. It is not elitism to fight what the late Dr. Alexander Wittenberg described as "educational inflation," a process which postpones the mastery of indispensable academic skills until finally universities are compelled, at extravagant cost, to instruct their matriculants in basic algebra and English composition.

On the other hand, it is time that universities recognized that formal education may be inferior to human experience as a preparation for post-secondary study. If there is a reform whose time has come, it is the abolition of the notion that education is a process divinely ordained for those between the ages of six and twenty-one. There is no revealed law of human development which even suggests that the posibilities of a university are best available for those between their seventeenth and twentieth year, and there is ample experience to the contrary. Generally speaking, across Canada, we make it as difficult as we can for a youngster to leave school before an arbitrary age. We make it as easy as we can for a favoured share of high school graduates to go directly to university, even when every thing in their souls cries out for the challenge of real life. Then, once they have become adults, with families and responsibilities, we make it incredibly difficult for people to do more than dabble for a decade with part-time degree courses.

Anyone who has ever taught mature students knows the general folly and the specific injustice of this state of affairs. Who better can appreciate literature, philosophy or history than those who have experienced humanity itself. Across Canada, the greatest untapped pool of ability lies with those - a majority of them women - who grew past the university age without its invitation even being extended.

In most of Canada, birthrates are falling. As the postwar baby boom passes through the post-secondary system, enrolments from the usual cohort of participants have stabilized and, by the early 1980's, will probably fall. The population grows older and the prospect of supporting a nation of pensioners replaces the tensions of the youth explosion as a fresh concern for public policy-makers. The need to recycle people as well as tin cans and news- 
print becomes more urgent as the pace of obsolescence in expertise and technique accelerates. As mankind seeks ways of reducing the consumption of energy and materials, the idea of an educative society becomes less utopian. Whatever its other defects, education is only a modest consumer of scarce resources.

Anyone associated with a university or community college can testify that students armed with every formal qualification have enrolled without the slightest hope of satisfaction. Propelled into the institution by parental pressure, a grim awareness of certification demands or a simple lack of easy alternatives, many students find themselves bored, exasperated and ultimately debilitated by their exclusion from the real world. They wait in frustration, enduring the final stage of the longest rite de passage yet designed by any tribe of the human race.

Relief may be in sight. A society of rising average age may soon have more urgent tasks for its young than resentfully cluttering its classrooms. In return, it will have to recognize that education is a right of maturity as well as of youth. Mature students will be needed by universities and colleges: in return, they may impose heavy demands on these institutions and on those who bear the costs. Mature students will expect more from their teachers and they will need a much higher level of financial support as they seek to maintain a life-style and a family. The benefit, for both society and institution, will be a more solid commitment to learning. For most mature students, education is not a mere obstacle course on the way to an officially certified maturity: it is a chosen goal. Their attitude can be contagious. As some can testify from experience, older students have as little patience with slipshod fellow students as with indifferent teachers, and the standards of both improve.

Unfortunately, more demanding and committed students will do much more to improve the quality of university teaching than other alleged improvements looming over the horizon. In the wake of pronouncements of concern about teaching by politicians, university presidents and their respective acolytes, there is some risk that professors may be tumbled into the same morass of educational "methodology" that Hilda Neatby discovered in Canadian high schools a generation ago. Like curriculum development institutes, academic hardware salesmen and peregrinating evaluators of departmental efficiency, methodology and its language, "Educator's English," belongs to the world of administrators, not teachers. Teaching is an art, learned from experience and association. Universities must, however, accept greater responsibility for ensuring that the art is acquired. Junior faculty must no longer assume major teaching responsibilities with no more than cautionary recollections of former professors and a few scraps of corridor lore.

The university's standard of teaching might be improved if those prominent academics who have found fresh careers as public oracles would choose between the classroom and politics. In the era of the university power trip, it seemed easier to change the world by walking with the mighty or their surrogates, exchanging a few secrets and much gossip. That era is over. If university teachers cannot transmit to their students the values and the analytical tools with which to make sense of their world, they have no special right to proclaim themselves as special messengers to the mighty.

There may be no message, however, if the universities succumb to the recurring campaign to divorce teaching and research. A frightening alliance of students, taxpayers and government is gathering for a fresh assault on universities as centres of research and independent scholarship and academics should have no illusions about their vulnerability. A few absurdly 
esoteric research topics, scholars whose research ended years ago with a marginal thesis, others whose productivity is now limited to gentlemanly farming; all will be targets to split the vital union of teaching and creativity.

Universities must be prepared to mobilize counter-arguments. Without continuous exploration at the frontiers of their subject, professors will soon have nothing worth teaching. They will almost inevitably fall into the kind of sterile repetition which most thoughtful students have condemned in their high school experience. In spite of some student claims, there is substantial evidence that active scholars are also effective teachers - particularly for that critical core of students who are also committed to learning. It is also apparent that there are or will be enough talented people who can combine research and teaching if only universities can be persuaded to make room for them.

University-based research, like universities themselves, cannot be allowed to stop simply because a severe economic squeeze happens to coincide with a particularly savage irrationalist assault. Faced with a bewildering array of problems, from the technology of tar sands development or of drilling for oil on the Atlantic shelf to the prospect of racial tensions in Canadian cities, we need a more effective mobilization of our organized intelligence than at any time since the Second World War. However, if humanity faces only half the crises now promised by the philosophers of doomsday, the universities will soon be competing with a lusty array of charlatans and demagogues, each with a vested interest in curbing serious thought and rational analysis.

In such circumstances, the Canadian academic community will need the unpractised virtues of courage and solidarity. Affluence has made them rusty. Taking a stand is so regularly condemned as "over-reaction", that academics seem to have an occupational predisposition for sitting down. And, once seated, no issue is ever so clear that a committee of professors cannot manage to produce both a compromise and a minority report. These may be the symptoms of a community that, to its credit, prefers discourse to violence. Interminable discourse and invariable reconsideration could also contribute to the death of the university as we know it.

The academic community in Canada does not face an early or a comfortable return to public esteem. Its role remains the same - to hold a mirror to our society, allowing neither a flattering self-portrait nor an outsider's caricature but reality. It is the role of an honest friend. As both educator and analyst of its society, the university community can look forward to being more needed and less wanted than at almost any earlier period in its history. 